\title{
GEOWIZUALNE BAZY DANYCH A REPRODUKOWANIE PSYCHOSOCJOLOGICZNYCH MITÓW POZNAWCZYCH
}

\begin{abstract}
Luczys Piotr, Geowizualne bazy danych a reprodukowanie psychosocjologicznych mitów poznawczych [Geovisual databases and reproduction of psychosociological cognitive myths] edited by M. Krajewski - „Człowiek i Społeczeństwo”, vol. XXXVI, iss. 2, Poznań 2013, pp. 215-237. Adam Mickiewicz University Press. ISBN 978-83-232-2672-7. ISSN 0239-3271.

The development of geographic information accompanied by the expansion towards accumulation of the greater and greater amount of geospatial data - initiated the specific theoretical marriage of reflection on objectivizing character of the digital imago mundi and the cognitive relationship between the "state of the world" and the "state of the mind". Whereby, electronic repositories of "geoevery-kind" data constitute the direct articulation of consciously acquiring and organising spatial data, additionally supported by the evidence of emergence of the new and inspired by "the sciences of cognition" (that is: cognitive psychology, cognitive science, philosophy of the mind, etc.) technological solutions in this realm. Such a theoretically-technical amalgam of information considerably limits - and being the clue of this paper - the explanatory usefulness of digital spatial data in the sociological analysis and deforms the contemporary state of knowledge regarding spatially-driven collective behaviours, leading to the rise of the mentioned myths.
\end{abstract}

Piotr Luczys, Uniwersytet im. Adama Mickiewicza w Poznaniu, Instytut Socjologii, ul. Szamarzewskiego 89c, 60-569 Poznań, Poland.

Kiedy mówimy o „bazach danych geoprzestrzennych”, przychodzą nam na myśl takie serwisy internetowe, jak Zumi, Google Earth, NASA World Wind, Google Maps, a także różne rodzaje lokalizatorów internetowych, których popularność i ogólnodostępność zaowocowała rozkwitem zupełnie nowych zjawisk czy dziedzin wiedzy (np. gCommerce ${ }^{1}$, geoinformacja ${ }^{2}$,

\footnotetext{
1 "gCommerce is a term [...] intersection of GIS and eCommerce, so as with eCommerce, there are business models within gCommerce; the main ones being B2C (Business to Customer), B2B (Business to Business) and G2C (Government to Citizen)", R. Crowley, gCommerce. How GIS is facilitating modern business, 2006, http://www.ronancrowley.com/NCI/gCommerce. pdf, s. 10 [dostęp: 30.11.2012].

${ }^{2}$ Geoinformację można najkrócej zdefiniować jako naukę eksplorującą dane geoprzestrzenne na podstawie standaryzującego i obiektywizującego odwzorowywania rzeczywistości
} 
geomarketing, systemy inwigilacji przestrzennej etc.), zaprzątających obecnie uwagę reprezentantów różnych dyscyplin nauki, m.in. socjologów. Jeśli jednak zamierzamy dokładniej eksplorować temat danych geoprzestrzennych (danych przestrzennych dotyczących powierzchni Ziemi) i ich geowizualizacji ${ }^{3}$, konieczne jest skierowanie naszej uwagi na bardziej prymarny poziom rozumienia, czym jest "geoprzestrzenność” jako taka. W potocznym odbiorze jest ona tym, co łączy Internet oraz nowe media z obrazem Ziemi, w możliwie szerokim (jak na ludzką wyobraźnię) spektrum wymiarów obrazowania - zwykle czterech: wysokości, szerokości, głębi i czasu. Wymiarów może być jednak nieskończona liczba, a dodanie do obrazowania przestrzeni Ziemi każdego kolejnego (piątego, szóstego itd.) jest ograniczone wyłącznie potrzebami użytkowników wskazanych wcześniej programów. Przykładowo, serwis Google Earth Builder, łączący funkcję baz danych Google Earth i Google Maps, umożliwia publikowanie własnych danych przestrzennych, transformowanie już istniejących oraz ich przesyłanie pomiędzy różnymi aplikacjami (w tym także na telefony komórkowe wyposażone w system operacyjny Android), co stanowi alternatywę nie tylko dla drogich licencji na oprogramowanie typu GIS4 (np. rozwijany od prawie piętnastu lat pakiet GeoMedia), ale i dla dywersyfikujących funkcjonalności tych systemów projektów typu „open source" ${ }^{5}$. Zgodnie z ustawą o infrastrukturze informacji przestrzennej z 2010 roku wyczerpuje to zakres tzw. „usług danych przestrzennych"6. Wspomniane portale, poza pełnieniem funkcji baz danych, są także - w rozumieniu leksykonu Polskiego Towarzy-

przestrzennej Ziemi, której nadrzędnym celem jest wymiana informacji geograficznej; zwana jest także „geomatyką".

${ }^{3}$ Geowizualizacja rozumiana jako „wizualizacja danych geograficznych [...] jest to obszar badań zajmujących się teorią, metodami i rozwiązaniami technicznymi wizualnego poznania, analizy, syntezy i prezentacji danych przestrzennych. Celem geowizualizacji jest również wspomaganie procesu budowania wiedzy poprzez wypracowywanie technik i rozwiązań technologicznych pozwalających na wizualną interakcję użytkownika z dostępnymi danymi i prezentowanie tych ostatnich $\mathrm{w}$ formie graficznych modeli rzeczywistości odniesionych przestrzennie. Często terminem tym określane są wszelkie formy prezentacji danych przestrzennych. Wśród tych form należy wymienić przede wszystkim mapy, ale również prezentacje trójwymiarowe, a także multimedialne", M. Andrzejewska et al., O partycypacji społecznej $w$ planowaniu przestrzennym. Zastosowania geowizualizacji $w$ celu wzmocnienia udziatu spotecznego w planowaniu przestrzennym, 2007, http://pspe.gridw.pl/movies/O\%20partycypacji_spolecz nej.pdf, s. 10 [dostęp: 30.11.2012].

${ }^{4}$ Geographic Information System (System Informacji Geograficznej) - typ oprogramowania, jakim posługuje się geoinformacja $\mathrm{w}$ celu gromadzenia, przetwarzania i wizualizowania danych geograficznych. Por. P.A. Longley, M.F. Goodchild, D.J. Maguire, D.W. Rhind, GIS. Teoria i praktyka, Warszawa 2008, s. XIII-XIV.

${ }^{5} \mathrm{http://opensourcegis.org/} \mathrm{[dostęp:} \mathrm{30.11.2012].}$

${ }^{6}$ J. Gaździcki, hasło: „usługi danych przestrzennych”, 2010, http://ptip.org.pl/ [dostęp: 30.11.2012]. 
stwa Informacji Przestrzennej (PTIP) - „geoportalami”, co oznacza, że jako „witryna internetowa lub jej odpowiednik, zapewniają dostęp do usług danych przestrzennych"7 oraz do "metadanych", czyli - w interesującym nas kontekście - "danych o danych [...] przestrzennych”, określających je pod względem „położenia i rodzaju obiektów oraz ich atrybutów, pochodzenia, dokładności, szczegółowości i aktualności danych zbioru, zastosowanych standardach, prawach własności i prawach autorskich, cenach, warunkach i sposobach uzyskania dostępu do danych zbioru oraz ich użycia w określonym celu" ${ }^{8}$. Jak łatwo się domyślić, Google Earth Builder oferuje możliwość kreowania własnych metadanych i to, w znaczącym zakresie, zupełnie darmowo (także w powiązaniu z tzw. geotaggingiem ${ }^{9}$ ). Z kolei oprogramowanie GIS typu „open source” umożliwia potraktowanie jako „danych geoprzestrzennych" wszelkich danych, którym można przypisać atrybut usytuowania $\mathrm{w}$ pewnej przestrzeni (np. programy zajmujące się „mapowaniem sieci”10 za swoją płaszczyznę odniesienia biorą rozległość powiązań sieciowych zamiast powierzchni Ziemi). „Bazy danych geoprzestrzennych" oraz powiązane z nimi oprogramowanie nie stanowią zatem wyłącznie nowego kroku na drodze rozwoju geografii i dyscyplin powiązanych, ale są również wyrazem nowego sposobu kodowania ludzkiej kompetencji orientowania się $\mathrm{w}$ otaczającym świecie, który we współczesnej humanistyce bywa utożsamiany ze zbieractwem, fetyszyzującym katalogowaniem, "obsesją archiwizowania" i porządkowania, pozostając zwierciadłem uniwersalnego, metafizycznego napięcia w ludzkim poznaniu, pomiędzy dążeniem do jego zupełności a użytkowym wykorzystaniem zgromadzonych za jego pośrednictwem informacji, akumulowanej $\mathrm{w}$ ten sposób wiedzy.

Samo rozumienie "danych geoprzestrzennych", będących podstawą informacji geograficznej (a zatem uzyskanej na drodze interpretacji danych geograficznych), współcześnie - w dobie powszedniejących systemów geo-

7 J. Gaździcki, hasło: „geoportal”, 2010, http://ptip.org.pl/ [dostęp: 30.11.2012].

8 J. Gaździcki, hasło: „metadane”, 2010, http:// ptip.org.pl/ [dostęp: 30.11.2012].

9 "Proces łączenia informacji o położeniu danego punktu (jego współrzędnych geograficznych) z innymi dotyczącymi go danymi, takimi jak strony internetowe, wiadomości RSS, cyfrowe fotografie czy filmy. Geotagi można dodać praktycznie do każdego zestawu danych posiadających datę i czas ich zebrania (tzw. time stamp)", http://pl.wikipedia.org/wiki/ Geotagging [dostęp: 30.11.2012].

${ }_{10} \mathrm{Na}$ temat kategorii web mapping por. S. Daniel, K. O'Rourke, Mapping the Database: Trajectories and Perspectives, "Leonardo" 2004, no. 4(37), s. 287-296; O. Gilson, N. Silva, P.W. Grant, M. Chen, From Web Data to Visualization via Ontology Mapping, "Computer Graphics Forum" 2008, no. 3(27), s. 959-966; W.G. Griswold, J.J. Yuan, Y. Kato, Exploiting the Map Metaphor in a Tool for Software Evolution, [w:] ICSE '01 Proceedings of the 23rd International Conference on Software Engineering, ed. H.A. Müller, Washington 2001, s. 265-274; P. Fu, J. Sun, Web GIS: Principles and Applications, Redlands 2010, passim. 
informacyjnych - implikuje konieczność przewartościowania właściwego im nazewnictwa. Znaczenie przedrostka "geo-", w licznych przywołanych pojęciach, zmienia nieco swój status, stanowiąc również symbolizację nowego kroku (szeroko rozumianego, nieodwracalnego „mariażu” geograficzno-informatycznego ${ }^{11}$ ) w rozwoju eksplorowania danych przestrzennych. Ich wzajemny związek wydaje się na tyle silny, że liczni autorzy coraz częściej - mówią dziś o przejściu od rozumienia skrótu GIS jako Geographic Information System do Geographic Information Science ${ }^{12}$, uznając tym samym geoinformację za najwyższe stadium rozwoju informatyki i geografii, które coraz mocniej poszerza swój zakres dziedzinowy (np. dane geoaudialne ${ }^{13}$ czy lokalizatory audioprzestrzenne) i stara się zarazem dokonywać swojego dyscyplinarnego uprawomocnienia, odnosząc się do schedy historiograficznie "starszych" nauk, m.in. nauk o poznaniu. Posiłkując się przykładami, trudno wyobrazić sobie takie pojęcia, jak "geoprzestrzeń" czy "geomedia", bez jednoczesnego odwołania i do geografii, i do informaty$\mathrm{ki}^{14}$, ale zarazem nie sposób myśleć o danych "geoprzestrzennych" jako jednorodnym wewnętrznie zbiorze informacji. Na użytek dalszej części tekstu dokonuję dwojakiego ograniczenia, zawężając zakres swoich rozważań wyłącznie do danych stricte geoprzestrzennych oraz wyłącznie do tych spośród nich, które są ilustrowane mapograficznie (czyt. „wyłącznie za pośrednictwem mapy"), z pominięciem diagramów, form wirtualnych, panoram, globusów, animacji oraz innych form "danych geowizualnych" (stanowiących zbiór nadrzędny względem danych geoprzestrzennych). Zakładam także, że podstawą tworzenia danych geoprzestrzennych jest geoinformacja, z zastrzeżeniem, że podstawą kreowania danych geowizualnych może być także np. geografia fantastyczna lub kartografia poznawcza (często - błędnie - utożsamiana z kartografią kognitywną ${ }^{15}$ ), na gruncie których tworzenie relacji poznawczej pomiędzy przedmiotem mapogra-

11 P.A. Longley, M.F. Goodchild, D.J. Maguire, D.W. Rhind, op. cit., s. IX-XII. Niekoniecznie związany z (sygnalizowanym przez autorów) „wnoszeniem nowych treści” i pojęć. Analogiczna sytuacja występuje w przypadku pojęcia "geowizualizacji", które nie znalazło się w leksykonie PTIP.

12 Por. D.Z. Sui, M.F. Goodchild, GISas Media?, „International Journal of Geographical Information Science" 2001, no. 5(15), s. 387-390; J. Kozak, GIS jako nowe narzędzie badań geograficznych: czy tylko?, „Alma Mater" 2006, nr 85, s. 22-24.

${ }^{13} \mathrm{http}: / /$ www.youtube.com/watch?v=7rGOj8TSHH4 [dostęp: 30.11.2012].

14 Warto zwrócić uwagę, że współcześnie oba terminy są rozczytywane wyłącznie w odniesieniu do idiomatyki właściwej dla oprogramowania GeoMedia firmy Intergraph, http://www.intergraph.com/sgi/products/default.aspx [dostęp: 30.11.2012]. Intuicyjnie potrafimy jednak odnosić termin "geomedia" do wszystkich narzędzi technologicznych, których podstawowym zadaniem jest przekazywanie danych typu "geo-", np. do wirtualnych globusów czy lokalizatorów sieciowych.

15 B. Medyńska-Gulij, Kartografia i geowizualizacja, Warszawa 2011, s. 10-11. 
ficznym a podmiotem poznającym jest ważniejsze niż zawiązywanie relacji komunikacyjnej (umożliwiającej wymianę „informacji geograficznej”) pomiędzy nimi. Tym samym relacja taka może mieć charakter afektywny (ekspresja oraz wzbudzanie emocji), regulacyjny (określający zasadność wyobrażeń przestrzennych, konfrontowanie ich z rzeczywistością), imaginatywny (prezentowanie "myślenia przestrzenią" na podstawie poznawczych kategorii przestrzennych, a nie wzorów obiektywizacji przestrzennej, np. układu kontynentów, rzędów wielkości powierzchni, geometryzacji i standardów metrycznych) lub po prostu heurystyczny (stopniowanie przejrzystości lub nieczytelności obrazowania wyobrażeń przestrzennych w zależności od zadania wizualizacyjnego, np. kodyfikacja symboliczna lub zobrazowanie poziomu skomplikowania). "Geowizualność” w refleksji geoinformatycznej pozostaje jednak podporządkowana wyłącznie definiowaniu w kategoriach obiektywizujących. Dla przykładu, Beata Medyńska-Gulij rozumie geowizualizację jako „wykorzystanie wizualnych reprezentacji informacji geoprzestrzennej do ułatwienia myślenia, zrozumienia i budowania wiedzy o aspektach środowiska człowieka i środowiska fizycznego typowych dla skal geograficznych oraz kreowania reprezentacji wizualnych dla tych aspektów"16. Uproszczenie, nakazujące uznać obiektywny charakter wszelkich danych geowizualnych, pozostaje niewrażliwe na idealizacyjny charakter tych spośród nich, które nie występują nigdzie poza rozpatrywaniem idealnotypologicznych rzeczywistości przestrzennych (np. tak w topologii matematycznej, jak i lokalnych mitach czy legendach), natomiast w formach aplikacyjnych i użytkowych przybierają postać "danych geowizualnych", których - najogólniej - wartość informacyjna (a zarazem ich przejrzystość i intersubiektywna komunikowalność) zbudowana zostaje nie tyle na uniwersalizujących standardach i odwołaniach do „idealnych rzeczywistości” (zinternalizowanych jako wzór doświadczania przestrzeni przez ludzi), ile na współpodzielanych stereotypizacjach przestrzennych, właściwych zarówno dla nadawców, jak i odbiorców „informacji geograficznych". W tym sensie możemy mówić o danych geowizualnych jako pewnej formacji ideologicznej (stanowiącej wyraz wyobrażeń przestrzennych naszych czasów), której głównymi nośnikami i replikatorami są właśnie systemy informacji geograficznej (GIS).

Nie chodzi jednak o „ideologizację" kojarzoną pejoratywnie w dyskursach potocznych, lecz o momenty powstawania danych geoprzestrzennych, w których dają o sobie znać wartości, światopoglądy i formacje poznawcze mające regulacyjny wpływ na wizualny charakter stosowanych odwzorowań. Tak dzieje się m.in. podczas georeferencji („wpasowanie treści karto-

\footnotetext{
16 Ibidem, s. 15.
} 
graficznej w układ współrzędnych przez przyporządkowanie określonych wartości współrzędnych odpowiednim punktom na mapie"17), przypisywania atrybutów ${ }^{18}$, stosowania mieszanych metod mash-up do tworzenia map $^{19}$, a nawet podczas standaryzowania formatów kartografii multimedialnej $^{20}$. Obiektywizm reprezentacji kartograficznych konstruowany przez standaryzowane obrazowanie rzeczywistości był wielokrotnie pozbawiany zasadności, także $\mathrm{w}$ refleksji samych geografów i kartografów, pośród których np. Mark Monmonier z Syracuse University w stanie Nowy Jork poświęcił mu aż 14 tytułów książkowych (m.in. w kontekście TV, prowadzenia działań wojennych, inwigilacji, meteorologii, demografii, informatyki i historii wyobrażeń geograficznych). Powściągliwa recepcja jego prac przywołuje na myśl maksymę Louisa Althussera, zgodnie z którą, „jeśli wzbraniamy się przed określaniem czegoś jako ideologia, to bardzo prawdopodobne, że to właśnie nią jest"21. Jeden z istotniejszych przykładów odwoławczych dla krytyków "obiektywizmu kartograficznego" to napięcie pomiędzy jednostkowym a zbiorowym doświadczaniem przestrzeni, które $\mathrm{w}$ aspekcie społecznym jest własnością emergentną i nieredukowalną do poziomu doświadczających indywiduów. Postępującej indywidualizacji narzędzi geoinformacyjnych (np. zapisywanie "ulubionych tras" w GPS, lokalizowanie i namierzanie jednostkowego położenia, przeglądanie danych geoprzestrzennych zgodnie ze zdefiniowanymi przez siebie landmarkami) towarzyszy bowiem definiowanie zbiorczych kategorii użytkowników danych geoprzestrzennych, a co za tym idzie - rozpoznawanie społecznego zapotrzebowania na kreowanie określonych danych. Pomiędzy uniwersalizacją a indywidualizacją doświadczenia przestrzennego zachodzi zatem elementarna sprzeczność: percepcja i przyswajanie przestrzeni przez samotnego wędrowca $\mathrm{w}$ nieznanym sobie mieście, turysty, zwiadowcy czy mieszkańca nawykowo wykorzystującego potrzebne do zaspokojenia swoich potrzeb szlaki komunikacyjne są odmienne od optyki miejskiego tłumu, publiki masowych wydarzeń, zbiorowości kibiców, uczestników spontanicznych zbiegowisk czy demonstrantów. Tym, co jednak łączy obie perspektywy doświadczania przestrzeni, jest proces wyprzedzający percepcję, na którą tak silnie pozostaje zorientowany obiektywizujący aparat kartografii.

Mowa tu o procesie kognicji, który powinien uzyskać kluczowy status przy badaniu relacji pomiędzy elementami umysłu a elementami otoczenia

\footnotetext{
17 Ibidem, s. 87.

18 Ibidem, s. 91.

${ }^{19}$ Ibidem, s. 191 - stosowanie różnych elementów w celu uzyskania innego, nowego obrazu przestrzeni.

20 Ibidem, s. 194

${ }^{21}$ K. Nawratek, Ideologie w przestrzeni. Próby demistyfikacji, Kraków 2005, s. 28.
} 
przestrzennego człowieka. Ten najbardziej prymarny proces poznawczy podążając śladem refleksji Włodzisława Ducha - ma dwa źródła definicyjne. Pierwsze z nich to nauki o komunikowaniu i związana z nimi refleksja na temat kognicji jako mentalnej projekcji idealnych, oczekiwanych i historycznych stanów świata, warunkującej nasze skojarzenia i tworzącej reguły komunikowania o nich $\mathrm{w}$ społeczeństwie (np. według teorii komunikacji kognitywnej Michaela Fleischera) ${ }^{22}$. Drugie z kolei to filozoficzny dualizm pomiędzy „wiedzą" lub „znajomością” (łac. cognitio) a anglojęzycznym "poznaniem" (czyli cognition), mającym również dwoistą postać znaczeniową: "dochodzenia” (np. prawdziwości) oraz „obejmowania świadomością" (tzn. korzystania z wiedzy towarzyszącej poznawaniu). Dodatkowych uzasadnień i teoretyczno-empirycznych uprawomocnień pierwotności kognicji względem percepcji dostarczają twierdzenia innych dyscyplin szczegółowych, np. problem percepcji środowiskowej wyartykułowany przez Williama H. Ittelsona. Wskazuje on, że uogólnianie każdego rodzaju percepcji do poziomu percepcji środowiskowej prowadzi do rozmycia kategorii poznania (które z kolei uważa za konstytutywne dla percepcji) ${ }^{23}$. O ile zatem możemy mówić o rozróżnieniu percepcji i kognicji na poziomie tłumaczenia ich samych, o tyle nie możemy mówić o ich rozdzieleniu na poziomie poznania. Zarówno zestawienie "percepcja i poznanie”, jak i „kognicja i poznanie” zawsze wikłają elementy tego drugiego członu właśnie w ramach poznania, zaś próby ich rozdzielenia generują liczne problemy (także na gruncie analiz socjologicznych), m.in.: nieostrości definicyjnej (kognicję zaczynamy tłumaczyć w kategoriach percepcji i odwrotnie), rezonerstwa (bezprzedmiotowe dowodzenie oczywistości - celem jest bowiem „poznanie”, bez niego eliminujemy przedmiot), mnożenia sofizmatów (twierdzenia pozornie prawidłowe, np. nierespektujące złożoności kategorii poznania) oraz solipsyzmu (indywidualizacja „poznania”, ale i dywersyfikacja jego poszczególnych elementów do poziomu jednostkowych, samotłumaczących swoją istotowość i istotność poznawczą procesów).

Obowiązująca na gruncie geoinformacji skłonność do zacierania wskazanych dualizmów i napięć prowadzi do premiowania perspektyw obiektywizujących, wystandaryzowanych na podstawie sformalizowanego aparatu matematycznego. Tym samym wyjaśnienie tworzenia, przyswajania oraz interpretacji danych geoprzestrzennych wymaga wykorzystania teorii obliczeniowych świadomości, algorytmizujących ludzkie procesy poznaw-

\footnotetext{
22 Tzn. tworzenie uzasadnień i odpowiedzi na kluczowe pytania, np. w kontekście tożsamościowym: ,jak jest?", ,jak było?", ,'co będzie?", ,z czego to wynika?" itd.

${ }^{23}$ Por. W.H. Ittelson, Environmental Perception and Urban Experience, "Environment and Behavior" 1978, no. 2(10), s. 193-213; idem, Visual Space Perception, New York 1960, passim.
} 
cze (np. komputacjonizm) ${ }^{24}$. Proste analogizowanie pomiędzy "strukturą świata" i "strukturą umysłu” przynosiło jednak ze sobą w historii nauki kolejne klęski przy konstruowaniu "myślących maszyn” i przerażenie humanistów, jakoby - słowami Andrzeja Kisielewicza - „odwieczne problemy filozofii, zagadki świadomości i umysłu rozwiązywali teraz matematycy i inżynierowie" 25 , co często dziś traktowane jest jako konstatacja kondycji współczesnej nauki, z którą nie sposób dyskutować wyłącznie w kategoriach słuszności lub jej braku. Nie można bowiem zaprzeczyć, że obwieszczenia humanistów o „końcu ery kartezjańskiej” 26 są obarczone dużą dozą przesady, a zastosowany analogon przyniósł także znaczące sukcesy naukowe, m.in. stworzenie obliczeniowego modelu mózgu czy osiągnięcia na gruncie matematyzacji percepcji, takie jak „rozpoznawanie wzorców” (pattern recognition). Ciągnąc jednak dalej wątek porażek, np. trychotomia projektów „sztucznej inteligencji" opierała się na konstruowaniu sztucznego ciała, zmysłów i umysłu27, przy czym ten ostatni projekt uważano za najbardziej wykonalny w świetle osiągnięć informatyki i logiki matematycznej. To przeświadczenie utrzymywało się od połowy lat pięćdziesiątych do końca lat siedemdziesiątych ubiegłego wieku, gdy zaczęto myśleć o odejściu od poszukiwania jednoznacznej definicji "sztucznej inteligencji” w kierunku modelowania komputerowego szczegółowych definicji umysłu. Do dziś są to zatem jedynie modele poszczególnych funkcji, procesów i mechanizmów działania, pozbawione komplementarności - ze względu na brak progresu teoretycznego $\mathrm{w}$ tej materii, a także kolejne porażki inżynieryjne, które jedynie zbliżały się do pewnej „wizji” działania umysłu, wyrażonej w języku maszynowym algorytmów. Również współczesne neuronauki (np. neuropsychologia, neurofilozofia) i kognitywistyka ${ }^{28}$ podają w wątpliwość możliwość neuroobrazowego i motorycznego odtworzenia kognicji, a w ślad za nią - struktury umysłu. Metaforycznie, klęska odtworzenia ",architektoniki umysłu” i jego "kognitywnej architektury” ukazała nieadekwatność metody formalnej w naukach o poznaniu ${ }^{29}$, o czym przekonywał już pod koniec lat osiemdziesiątych XX wieku angielski matematyk i fizyk Roger Penrose, formułując postulaty o niemechanicznym charak-

${ }_{24}$ M. Miłkowski, Obliczeniowe teorie świadomości, „Analiza i Egzystencja” 2010, nr 11, s. $133-154$.

25 A. Kisielewicz, Sztuczna inteligencja i logika. Podsumowanie przedsięwzięcia naukowego, Warszawa 2011, s. 13.

26 Ibidem, s. 14.

27 Ibidem, s. 33-34.

${ }^{28}$ Por. Formy aktywności umystu. Ujęcia kognitywistyczne, t. 1: Emocje, percepcja, świadomość, red. A. Klawiter, Warszawa 2008 (zwłaszcza część III: Świadomość: qualia, subiektywność, neuronalne korelaty).

${ }^{29}$ A. Kisielewicz, op. cit., s. 62-63. 
terze ludzkiego umysłu ${ }^{30}$. Można zatem stwierdzić, że umysł "poznający” przestrzeń to umysł "motywowany kognitywnie" do uruchamiania procesów sensepcji31, percepcji i kategoryzowania otoczenia przestrzennego, na bazie kognitywnie skodyfikowanych wyobrażeń, oczekiwań, przypuszczeń itd. O ile zatem wyizolowanie percepcji jako funkcji umysłu daje się objać badawczo z perspektywy obliczeniowej, o tyle jej transgresyjne powiązanie z sensepcją i kategoryzacją (np. zależności mechanizmów psychicznych i biologicznych) nie spełnia warunków naukowo poprawnego wyjaśnienia (np. ze względu na obecność entymematycznych przesłanek, ale również ze względu na odmienny status ontologiczny przesłanek jawnych), a w konsekwencji - uniemożliwia „świadome” (w znaczeniu: przekraczające ramy standaryzacji obliczeniowej; wynikające $\mathrm{z}$ jednoczesności oddziaływania mechanizmów myślenia i poznania poddających się algorytmizacji, a także „niewrażliwych" na ten sposób przedstawienia) posługiwanie się tak wytworzonymi danymi. Ciekawym przypadkiem takiego "narzędziowego fetyszyzmu" jest wykreowanie nowych przestrzeni manipulacji w kartografii multimedialnej, np. kategorii tzw. „czasu rzeczywistego" i „rozszerzonej rzeczywistości" umożliwiającej dokonanie orientacji topograficznej (np. za pośrednictwem smartfona) poprzez przetworzenie obrazu obserwowanego (okiem kamery) na odnośny, istniejący obraz mapograficzny (zwykle trójwymiarowy), którego "rzeczywistościowy”, obserwacyjny charakter bywa zaburzany przez reklamy, projektowe dystraktory, wirtualną architekturę, zagadki wizualne etc., które pojawiają się na trójwymiarowej mapie ${ }^{32}$. Tym samym jego rozpoznawalność oraz referencyjny związek z mentalnym obrazem przestrzeni pozostaje jedynie skojarzeniowy, ograniczony biologicznymi i kulturowymi korelatami stanowienia wyobrażeń przestrzennych.

Uniwersalność danych przestrzennych oparta jest zatem na selektywnym i niekomplementarnym charakterze licznych, obiektywizujących obliczeniowo ludzkie poznanie (np. parametryzujących, algorytmizujących itd.) teorii, co rodzi zastrzeżenia dotyczące poznawczo obiektywnego przyswajania i przetwarzania tych danych, które to procesy również - jako czynności poznawcze - podlegają opisowi z punktu widzenia założeniowo przyjętej natury ludzkiego umysłu. To zwykłe uproszczenie, ale o doniosłych konsekwencjach, jeśli uzmysłowimy sobie fakt, że przestrzeń jako kategoria

30 Por. R. Penrose, Nowy umyst cesarza. O komputerach, umyśle i prawach fizyki, Warszawa 2000, passim; idem, Cienie umystu. Poszukiwanie naukowej teorii świadomości, Poznań 2000, passim.

31 „Zespół bezpośrednich i niezwłocznych neuronalnych reakcji organizmu na bodźce ze środowiska", A. Klawiter, Wstęp do kognitywistyki. Wyktad siódmy, http://www.staff.amu. edu.pl/ klawiter/wstep-wyklad7-2010.pdf [dostęp: 30.11.2012].

32 B. Medyńska-Gulij, op. cit., s. 196-202. 
mentalna nie jawi się nam na płaszczyźnie świadomości w formie odpowiadającej tradycyjnym reprezentacjom danych geoprzestrzennych (oba typy obiektów posługują się innym ,językiem wizualnym”). To z kolei często prowadzi do powiązania obliczeniowych i materialistycznych (utożsamiających mózg i umysł33) teorii ludzkiego umysłu, które na drodze redukcji dokonują dopasowania obu płaszczyzn (podmiotowej i przedmiotowej) poznawczych do siebie. Tego typu formy analogizowania różni autorzy utożsamiają z poszukiwaniem korelacji "po omacku”, dla którego wymyślają mniej lub bardziej pejoratywne określenia w różnych kontekstach ${ }^{34}$. W socjologii, ogólnie, stanowi to punkt wyjścia do sporu pomiędzy społeczno-kulturowym a socjobiologicznym wyjaśnianiem zachowań zbiorowych, ale na interesującym nas poziomie oznacza uznanie ludzkiej wyobraźni przestrzennej za sprowadzalną do poziomu warunkowania właściwego dla matematyzacji danych („skrajny redukcjonizm”) lub uznania sposobów tworzenia oraz posługiwania się danymi geoprzestrzennymi za ekwiwalentne względem wszelkich poznawczych form przepracowywania wyobrażeń i doświadczeń przestrzennych w umyśle człowieka („skrajny idealizm"). Odrzucając oba te wnioski - ponieważ przyjęcie któregokolwiek z nich oznaczałoby zgodę na uznanie obiektywnego charakteru powiązań

33 Związana z materialistycznymi teoriami kwestia naturalizowania ludzkiego umysłu oraz fundowania na jego założeniach prac nad kolejnymi przekształceniami danych geoprzestrzennych (np. neurosieci) zbyt znacząco przekracza ramy tego opracowania, aby móc ją bliżej zrekonstruować na poziomie tekstu.

${ }^{34}$ A. Kisielewicz pisze o „konekcjonizmie” podporządkowanym idei „łączyć i łączyć, aż się coś (być może) wyłoni” (A. Kisielewicz, op. cit., s. 54) oraz o „ignoranckim redukcjonizmie" (ibidem, s. 337) robiącym karierę w kognitywistyce zorientowanej na formalny model metod naukowych, ale i o neurobiologii jako „początkującej”, jeśli chodzi o odkrywanie ogólnych praw działania mózgu i pokładającej nadzieję w "prymitywnej” nauce - w stosunku do budowy ludzkiego mózgu - jaką jest informatyka (ibidem, s. 350). Z kolei Chris Frith - określający samego siebie jako „neurobiologa poznawczego” (Ch. Frith, Od mózgu do umystu. Jak powstaje nasz wewnętrzny świat, Warszawa 2011, s. 13) - będący przeciwnikiem wyodrębniania bytu umysłowego jako odrębnego od mózgu, stwierdza, że ",treści umysłu nie są rzeczywiste" (ibidem, s. 27), ponieważ to mózg tworzy iluzję odrębności tego, co fizyczne, i tego, co umysłowe. Nie zmienia to jednak faktu, iż poznanie relacji „mózg (zmysły)-umysł” wymaga subtelniejszego podejścia niż obliczeniowe, ponieważ „większa część aktywności mózgu nigdy nie dociera do mojej świadomości. To jest to, o czym wie mój mózg, ale nie ja. Z drugiej strony mam głębokie przekonanie, że jestem wytworem swojego mózgu, tak samo jak świadomość, która mi towarzyszy" (ibidem, s. 35). Także John R. Searle, filozof umysłu, reprezentujący stanowisko radykalne przeciwstawne poglądom Fritha, argumentuje, że obliczeniowy model poznania zdyskredytował swoje szanse opisania działania umysłu, dowodząc, iż rozumienie nie jest potrzebne do wykonania określonego zadania (por. J.R. Searle, Umyst na nowo odkryty, Warszawa 1999, passim). Klasyczny dyskurs ilościowych modeli działania "mózgu-umysłu” wydaje się zatem wyczerpywać w bezproduktywności. Por. M. Miłkowski, R. Poczobut, Wprowadzenie, [w:] Przewodnik po filozofii umystu, red. M. Miłkowski, R. Poczobut, Kraków 2012, s. 16-17. 
pomiędzy danymi geoprzestrzennymi a strukturą ludzkich doświadczeń przestrzennych lub pomiędzy wytwarzaniem tych danych a ich recepcją musimy stwierdzić, że ludzkie poznanie stanowi, nadrzędną względem narzędzi geoinformacyjnych, jakość. Oferowane przez systemy GIS (oraz podobne) funkcjonalności, nawet jeśli właściwe dla nich sposoby obrazowania i prezentacji danych geoprzestrzennych przekraczają ramy nawykowego myślenia o przestrzeni i kategoryzowania powiązanych z nią doświadczeń, nadal pozostają podporządkowane głównym generatorom potencjalnych uproszczeń - kierowanym kognicją procesom poznawczym twórców i użytkowników danego oprogramowania. Ono samo nie może być doskonalsze ani oferować nic ponad to, co właściwe dla myślenia twórców i użytkowników (nie jest bowiem tworem „zewnętrznej” technologii ani dziełem przypadku). Jakość, technologia i sposób przetwarzania danych geoprzestrzennych za pomocą odpowiedniego oprogramowania nie stanowi zarazem "obiektywnego" obrazu procesu poznawania przestrzeni, otoczenia życia człowieka in se, a oczekiwanie pełnej zbieżności pomiędzy trajektoriami myślenia przestrzennego ludzi powinno zostać zastąpione przez szacowanie możliwego zakresu intersubiektywnej komunikowalności graficznych reprezentacji tego myślenia, nawet jeśli odbyłoby się to kosztem standaryzacji geograficznej. Tym, co powstrzymuje geoinformację przed dokonaniem podążającej $\mathrm{w}$ takim (subiektywizującym) kierunku zmiany, jest przedkładanie formalnego, standaryzującego charakteru dopiero krzepnącej dyscypliny ponad eksplanacyjną użyteczność (która koniec końców będzie podporządkowana wyłącznie doskonałości narzędzi technicznych, jakimi będzie się posługiwać geoinformacja), powinowactwo dyscyplinarne (związki z matematyką i informatyką) oraz dążność do potwierdzania filozofii wąskiej specjalizacji nauk - zgodnie z którą jasno wyznaczony obrys przedmiotu zainteresowań kwestionuje sens stawiania pytań o granice rzeczonego obrysu, przyległości, nieregularności itd. - a także przekonanie, że samo odwoływanie się do niej stanowi przejaw „dojrzałości” dyscyplinarnej we współczesnej nam epoce.

Reprodukcji wspomnianych wcześniej stereotypów poznawczych (np. obiektywne wytwarzanie i recepcja danych geoprzestrzennych, utożsamianie perspektyw obliczeniowych z materialistycznymi itd.) towarzyszy także wytwarzanie specyficznych schematów interpretacyjnych na gruncie nauki, w których arbitralność posługiwania się danymi geoprzestrzennymi staje się pochodną założeń inicjujących (zespolenie niekomplementarności i niezupełności teorii obliczeniowych umysłu z mającą odwoływać się do ludzkiego poznania standaryzacją obrazowania), a w konsekwencji prowadzi do wypracowania bezrefleksyjnej maniery posługiwania się tego typu danymi w różnych dyscyplinach nauki. Nie eksplorując szerzej tego wątku, ogra- 
niczmy się do problemów związanych z wykorzystywaniem danych geoprzestrzennych (za pośrednictwem narzędzi mapograficznych) tylko na gruncie socjologii ${ }^{35}$, przedstawionych w ujęciu tabelarycznym:

\begin{tabular}{|c|c|c|c|c|}
\hline $\begin{array}{c}\text { Czego szuka } \\
\text { socjologia? }\end{array}$ & $\begin{array}{l}\text { Co jest oferowa- } \\
\text { ne (pozornie) } \\
\text { przez dane geo- } \\
\text { przestrzenne? }\end{array}$ & $\begin{array}{l}\text { Co rzeczywiście } \\
\text { daja/pokazują } \\
\text { dane geoprze- } \\
\text { strzenne? }\end{array}$ & $\begin{array}{c}\text { Jak jest to } \\
\text { rozumiane } \\
\text { (w socjologii)? }\end{array}$ & $\begin{array}{c}\text { Źródło napięcia } \\
\text { pomiędzy "ofer- } \\
\text { tą" a "poszuki- } \\
\text { waniem" }\end{array}$ \\
\hline $\begin{array}{l}\text { poznawcze } \\
\text { kompresje oto- } \\
\text { czenia prze- } \\
\text { strzennego } \\
\text { (np. wizerunek } \\
\text { miasta) i czyn- } \\
\text { niki mentalne }\end{array}$ & $\begin{array}{l}\text { fotopunkty (np. } \\
\text { w aerofotograme- } \\
\text { trii), współrzęd- } \\
\text { ne, odwzorowa- } \\
\text { nia + oznaczenia } \\
\text { opisujące daną } \\
\text { przestrzeń }\end{array}$ & $\begin{array}{l}\text { wyskalowany } \\
\text { obraz prze- } \\
\text { strzeni (znaki } \\
\text { skalowe }{ }^{36} \text { ) + } \\
\text { skojarzeniowy } \\
\text { obraz prze- } \\
\text { strzeni (od zna- } \\
\text { ków symbolicz- } \\
\text { nych po znaki } \\
\text { zgeneralizowa- } \\
\text { ne37) + geome- } \\
\text { tryzacje atry- } \\
\text { butów }\end{array}$ & $\begin{array}{l}\text { kartometrycznie } \\
\text { (zgodność skal } \\
\text { wielkości rze- } \\
\text { czywistych } \\
\text { względem wiel- } \\
\text { kości odwzoro- } \\
\text { wanych); niein- } \\
\text { terpretowanie } \\
\text { podwójnych } \\
\text { standardów } \\
\text { symbolizacji }\end{array}$ & $\begin{array}{l}\text { obiektywizacja } \\
\text { obrazowa vs. } \\
\text { subiektywizacje } \\
\text { przestrzenne } \\
\text { (np. wspomnie- } \\
\text { niowe, płciowe, } \\
\text { kulturowe itd.) }\end{array}$ \\
\hline $\begin{array}{l}\text { doświadczanie } \\
\text { przestrzeni i jej } \\
\text { trwania, ciągło- } \\
\text { ści, przemian }\end{array}$ & $\begin{array}{l}\text { aktualizacja kar- } \\
\text { tograficzna (cią- } \\
\text { gła lub okresowa) }\end{array}$ & $\begin{array}{l}\text { ciąg statycznych } \\
\text { odwzorowań } \\
\text { w określonych } \\
\text { punktach czasu }\end{array}$ & $\begin{array}{l}\text { obraz przemian } \\
\text { przestrzennych } \\
\text { (błąd „reifika- } \\
\text { cji”38) }\end{array}$ & $\begin{array}{l}\text { aktualizacja } \\
\text { narzędziowa vs. } \\
\text { temporalizacja } \\
\text { poznawcza (inna } \\
\text { „rachuba czasu”) }\end{array}$ \\
\hline $\begin{array}{l}\text { używanie prze- } \\
\text { strzeni (np. } \\
\text { przemieszcza- } \\
\text { nie się w niej) } \\
\text { i czynniki be- } \\
\text { hawioralne }\end{array}$ & $\begin{array}{l}\text { dane obarczone } \\
\text { kilkukrotnymi } \\
\text { standardami } \\
\text { generalizacji } \\
\text { (ilościowej oraz } \\
\text { jakościowej) + } \\
\text { cyfrowanie } \\
\text { danych }\end{array}$ & $\begin{array}{l}\text { "statyczne" } \\
\text { znaki dyna- } \\
\text { miczne + wielo- } \\
\text { płaszczyznowe } \\
\text { poziomy gra- } \\
\text { ficzne map + } \\
\text { dokładność } \\
\text { geometrycznego }\end{array}$ & $\begin{array}{l}\text { następstwo in- } \\
\text { terwałów o jed- } \\
\text { nym standardzie } \\
\text { generalizacji } \\
\text { (przestrzeń, czas, } \\
\text { odsetek popula- } \\
\text { cji) + nie- } \\
\text { uwzględnianie }\end{array}$ & $\begin{array}{l}\text { "dynamika” } \\
\text { danych geogra- } \\
\text { ficznych vs. } \\
\text { "dynamika" } \\
\text { danych socjolo- } \\
\text { gicznych39 }\end{array}$ \\
\hline
\end{tabular}

35 Prezentowane ustalenia można jednak z powodzeniem odnosić do szerszej ramy nauk społecznych.

${ }^{36}$ Obrazy przedmiotów terenowych zmniejszone proporcjonalnie do mianownika danej skali.

37 Tzn. od obrazów skojarzonych z przedmiotem oznaczonym po symbol umowny, nieprzypominający swoją grafiką przedmiotu lub zbioru przedmiotów oznaczanych (np. miasto jako obrys obszaru wypełnionego deseniem kreskowanym lub kratkowanym).

38 Por. Ch.G.A. Bryant, Socjologia bez podstaw, [w:] Racjonalność wspótczesności. Między filozofia a socjologia, red. H. Kozakiewicz, E. Mokrzycki, M.J. Siemek, Warszawa 1992, s. 264.

39 Śledzenie jednego określonego czynnika przy jednoczesnym traktowaniu jako niezmiennych czynników pozostałych (zależy od przyjęcia określonego normatywizmu) vs. śledzenie jednego określonego czynnika na drodze jego wyodrębnienia, „uczytelnienia” na planie zestawu pozostałych czynników (zależy od konceptualizacji). 


\begin{tabular}{|c|c|c|c|c|}
\hline $\begin{array}{l}\text { Czego szuka } \\
\text { socjologia? }\end{array}$ & $\begin{array}{c}\text { Co jest oferowa- } \\
\text { ne (pozornie) } \\
\text { przez dane geo- } \\
\text { przestrzenne? }\end{array}$ & $\begin{array}{c}\text { Co rzeczywiście } \\
\text { daja/pokazują } \\
\text { dane geoprze- } \\
\text { strzenne? }\end{array}$ & $\begin{array}{c}\text { Jak jest to } \\
\text { rozumiane } \\
\text { (w socjologii)? }\end{array}$ & $\begin{array}{c}\text { Źródło napięcia } \\
\text { pomiędzy "ofer- } \\
\text { tą" a "poszuki- } \\
\text { waniem" }\end{array}$ \\
\hline & $\begin{array}{l}\text { (od wektorowego } \\
\text { modelu krajobra- } \\
\text { zowego do cy- } \\
\text { frowego modelu } \\
\text { kartograficznego) }\end{array}$ & $\begin{array}{l}\text { położenia vs. } \\
\text { zgodność geo- } \\
\text { graficzna }\end{array}$ & $\begin{array}{l}\text { progów genera- } \\
\text { lizacji i zasad } \\
\text { cartographic design } \\
\text { (kompozycja, } \\
\text { proporcje, kon- } \\
\text { trast, deseń, } \\
\text { głębia etc.) }\end{array}$ & \\
\hline $\begin{array}{l}\text { patologie } \\
\text { doświadczeń } \\
\text { przestrzennych } \\
\text { (poziom „od- } \\
\text { biorcy”) i „pu- } \\
\text { lapki kognityw- } \\
\text { ne” (niezamie- } \\
\text { rzony poziom } \\
\text { odwzorowania } \\
\text { i recepcji) }\end{array}$ & $\begin{array}{l}\text { prawdopodo- } \\
\text { bieństwo błędu } \\
\text { pomiarowego } \\
\text { (poziom „wy- } \\
\text { twórcy”), niedo- } \\
\text { pasowania na- } \\
\text { rzędziowego lub } \\
\text { "planowe defor- } \\
\text { macje” (np. mapy } \\
\text { anamorficzne) }\end{array}$ & $\begin{array}{l}\text { konkretne błędy } \\
\text { (np. inklinacji, } \\
\text { kolimacji, efekt } \\
\text { pseudoskopo- } \\
\text { wy }^{40} \text { ) po zmia- } \\
\text { nach w rastro- } \\
\text { wym modelu } \\
\text { danych i redun- } \\
\text { dancje graficz- } \\
\text { ne, ew. stan } \\
\text { wiedzy nie- } \\
\text { zgodny z obiek- } \\
\text { tywnym stanem } \\
\text { niewiedzy geo- } \\
\text { graficznej }\end{array}$ & $\begin{array}{l}\text { odwzorowanie } \\
\text { określonego } \\
\text { stanu wiedzy + } \\
\text { brak rozróżnie- } \\
\text { nia na „wytwór- } \\
\text { cę” i „odbiorcę” } \\
\text { (często wręcz ich } \\
\text { utożsamienie); } \\
\text { zakładanie } \\
\text { "uśrednionej” } \\
\text { kompetencji } \\
\text { kartograficznej }\end{array}$ & $\begin{array}{l}\text { „niedoskona- } \\
\text { łość” narzędzi } \\
\text { i „wprawnośćc } \\
\text { w posługiwaniu } \\
\text { się nimi vs. } \\
\text { "niewiedza” } \\
\text { geograficzna } \\
\text { i „niedoskona- } \\
\text { łość zmysłów"41 }\end{array}$ \\
\hline
\end{tabular}

Źródło: Opracowanie własne ${ }^{42}$.

40 To efekt powstający przy obserwacji lewego zdjęcia stereogramu (będącego złożeniem dwóch fotogramów - zdjęć tego samego obiektu wykonanych z dwóch różnych miejsc) prawym okiem, a prawego zdjęcia - lewym okiem (efekt wrażeniowy: wypukłości są wklęsłe, a wklęsłości - wypukłe).

41 „Przekłamania” odwzorowań geograficznych wynikają ze specyfiki technicznej urządzeń służących tworzeniu odwzorowań, a nie ludzkiego poznania, gdyż występowanie „pułapek kognitywnych" jest niezależne od tego, do jakich narzędzi technicznych się odwołamy. Jeśli zatem obraz „pułapek” zmienia się każdorazowo, gdy sięgamy po inne techniki ich odwzorowywania, to więcej mówią nam one (techniki) o sposobach ich tworzenia niż o rzeczonych "pułapkach".

$42 \mathrm{~W}$ odwołaniu do słownika terminów geograficznych (nie tylko związanych z systemami GIS) rekonstruowanego na podstawie: 1000 stów o mapach $i$ kartografii, red. J. Drabek, F. Piątkowski, Warszawa 1989, s. 13, 50-52, 64, 104-105, 400-405; F. Osowski, L. Brokman, Elementy kartografii. Redagowanie i reprodukcja map, Warszawa 1984, passim; K.A. Saliszczew, Kartografia ogólna, Warszawa 2003, passim; B. Medyńska-Gulij, op. cit., s. 24-25, 80-86, 96-103; S. Przewłocki, Geomatyka, Warszawa 2009, passim; P.A. Longley, M.F. Goodchild, D.J. Maguire, D.W. Rhind, op. cit., passim; D. Gotlib, A. Iwaniak, R. Olszewski, GIS. Obszary zastosowań, Warszawa 2007, passim; A. Robinson, R. Sale, J. Morrison, Podstawy kartografii, Warszawa 1988, passim. 
Opierając się na powyższym zestawieniu, możemy wyróżnić cztery podstawowe obszary zainteresowań socjologów, przy eksplorowaniu których sięgają oni po dane geoprzestrzenne (powiązane z pierwszą kolumną tabeli). Po pierwsze, eksploracje związane z dialektyką świadomości jednostkowej i świadomości społecznej, z oddziaływaniami pomiędzy "Ja" $\mathrm{i}$ "My" oraz z innymi wariantami napięć lokujących się na kontinuum „jednostka-społeczeństwo". Po drugie, przy wyjaśnianiu działaniowo-środowiskowych relacji pomiędzy całościami społecznymi i pozaspołecznymi (np. kontekst „otoczenia” życia społecznego, różne rodzaje grup w kontekstach ogólnospołecznych, dialektyka „natura-kultura” itd.). Po trzecie, na gruncie opisu zachowań społecznych oraz form wywierania wpływu i zawiązywania relacji pomiędzy aktorami życia społecznego; dokonując heurystycznego oddzielenia względem dwóch wcześniej wyszczególnionych obszarów, można to określić jako skupienie uwagi tylko na tym, co jest „toczeniem życia wyłącznie w aspektach społeczno-kulturowych", mechanicznym socjologizmem. I po czwarte, także w ramach szerokiej kategorii opisu dewiacji oraz patologii, symptomatycznej nie tylko dla wykrywania społecznych "nieprawidłowości”, ale i ukrytych normatywizmów oraz ograniczeń we wszystkich kontekstach towarzyszących temu, co społeczne (np. psychicznych, środowiskowych itd.). W każdym z tych wariantów socjolodzy prowadzą specjalistyczne eksploracje związane $\mathrm{z}$ tematyką przestrzenną (treść pierwszej kolumny), do których odnoszą się także specyficzne dane geoprzestrzenne (treść drugiej kolumny), ale nie w sposób bezpośredni, co wymaga ich rozczytywania przez pryzmat formacji wiedzowych, za pośrednictwem których zostały one stworzone (treść trzeciej kolumny). Obrazowo można powiedzieć, że „rozumienie” na gruncie geoinformacji i rozumienie na gruncie socjologii są odmiennymi rodzajami czynności poznawczych, nawet jeśli odwołują się do tej samej tematyki i ilustrujących ją danych. Mamy tu zatem do czynienia $\mathrm{z}$ niedostatkiem wiedzy specjalistycznej socjologów, jeśli chodzi o narzędzia techniczne oraz kilkutorową, krytyczną analizę map - jako narzędzi badawczych, form prezentacji wyników eksploracji teoretycznych i empirycznych oraz jako materiałów zastanych podlegających analizie (treść kolumny czwartej). Perspektywa ulega bowiem zmianie, gdy to nie elementy mapy stają się "danymi" dla socjologa, lecz gdy "dane" trzeba semiotyzować oznaczeniami kartograficznymi (np. ilustrując przestrzenne rozkłady wyników) lub gdy pozyskane dane (np. podczas badań terenowych) należy zakodować oznaczeniami mapograficznymi (np. aby zagregować odpowiedzi respondentów), a dopiero w kolejnym kroku "odsączyć” $\mathrm{z}$ nich informacje. Zasadnicze dla zrozumienia tych elementarnych rozbieżności poznawczych pomiędzy geoinformacją a socjologią jest wskazanie prymarnych napięć będących źródeł opisywanych niezgodności interpretacyjnych (treść piątej kolumny). 
Idąc krok dalej, z łatwością stwierdzimy, że sygnalizowane niezgodności są jednak wyłącznie - w szerszej perspektywie - efektami oddziaływania tytułowych "mitów poznawczych", jednakowo infekujących potoczne oraz naukowe myślenie o danych geoprzestrzennych i ich możliwych, "oczywistościowych" (jak często myślą socjolodzy) zastosowaniach. Czym jednak są "mity poznawcze"? Jest to rodzaj Feyerabendowskiej „skamieliny", tzn. zestalonej postaci tego, co w nauce traktowane jest jako zbiór twierdzeń bazowych, co do których wiara i przekonania badaczy są silniejsze niż ich potencjalna weryfikowalność empiryczna czy przydatność eksplanacyjna ${ }^{43}$. Utrzymują się w nauce wyłącznie ze względu na brak nowych (falsyfikujących obowiązujący stan rzeczy) hipotez, wywierając zarazem przymus intelektualny, nakazujący kierowanie się określonym sposobem myślenia oraz wizją uprawiania nauki (lub po prostu myślenia - jeśli mamy do czynienia $z$ "mitem poznawczym” poza kontekstem naukowym). Tym, co dla mitów poznawczych specyficzne, jest ich stosowanie w sytuacjach, w których dowodzenie (lub myślenie) wydaje się popadać w różnego rodzaju pułapki, jak się nam wydaje (np. paradoksy, dualizacje, przeczenia, idem per idem, ignotum per ignotum itd.), ale których obecności nie potrafimy lub nie chcemy udowadniać ( $\mathrm{z}$ braku czasu, odpowiedniego zasobu informacji, nie wierząc $\mathrm{w}$ płodność takich rozważań itd.). Podążamy zatem na skróty, omijając napotkaną trudność kosztem jakości dokonywanych eksplanacji, mitologizujemy potencjalne rozwiązania. Warunkiem niezbędnym wystąpienia mitu poznawczego jest zatem ufność w jego doniosłość i pomocniczy, ułatwiający wiązanie ze sobą faktów charakter, uniwersalność podpowiadanych przezeń rozwiązań. Odnosząc rozważania poświęcone mitom do sytuacji związku pomiędzy geografią i socjologią, w obrębie interesującego nas zagadnienia, powiemy, że konkretne dane geoprzestrzenne ulegają idealizacji do poziomu "danych geowizualnych" w efekcie zabiegów interpretacyjnych dokonywanych przez badaczy społecznych posiłkujących się materiałami mapograficznymi. Prowadzi to do uznania, iż przestrzenne zachowania zbiorowe nie są mapowane przez dane przestrzenne, nie mogą być, albo też - że dane te tworzone są tak, iż ich wykorzystywanie do opisywania przestrzennych zachowań zbiorowych prowadzi do błędnych wnioskowań. Ta „podejrzliwość” (której źródeł upatruję w niedostatecznym rozpoznaniu związków pomiędzy poszczególnymi procesami poznawczymi) wykorzystuje i pogłębia przepaść pomiędzy humanistyką a science. Gra idzie bowiem o interpretację zachowań ludzkich na gruncie science, która jest przekonana, że obraz tych zachowań, jaki posiada - jest obiektywny; z kolei na gruncie humanistyki - ten sam obraz traktuje się

${ }^{43}$ P.K. Feyerabend, Przeciw metodzie, Wrocław 2001, s. 36-38. 
jako inspirację do tworzenia kolejnych interpretacji, nie respektując zarazem faktu, że już on sam (obraz) jest "technologiczną interpretacją" tego, co społeczne. Tym samym więcej o danych przestrzennych mówią okoliczności ich tworzenia i środki ich stwarzania niż one same, a jeszcze więcej mówią o sposobach obrazowania przestrzennych zachowań zbiorowych niż o samych tych zachowaniach. W efekcie powstają rzeczone mity, przejawiające się w błędnie skodyfikowanych ścieżkach interpretacyjnych.

Jednym $\mathrm{z}$ takich mitów jest indywidualizacja doświadczeń przestrzennych ceteris paribus, a wyraża się on w przekonaniu, że jeśli nie istnieje żadna rozpoznana potencja grupotwórcza, uspołeczniająca, pomiędzy badanymi recepcjami otoczenia przestrzennego (np. pojedynczych mieszkańców różnych miast $\mathrm{w}$ odległych od siebie regionach świata), to nie wykazują one znaczących zbieżności dla wszystkich tych przypadków jako reprezentantów szerszych kategorii (np. istot posługujących się myśleniem abstrakcyjnym). Częściowo problem ten może ulec przezwyciężeniu przez adaptację technik skalowania wielowymiarowego (multidimensional scaling) do nauk społecznych lub standaryzację tablicy znaków i skal przy posługiwaniu się narzędziami mapograficznymi (jeden i drugi sposób pozwala stworzyć pewne kryteria „uwspólniania doświadczeń”). Ogólnometodologiczną wadą tego drugiego rozwiązania jest jednak popadanie w kolejną, przeciwległą radykalnej indywidualizacji, holistyczną wizję, stanowiącą zarzewie innych mitów naukowych o genealogii poznawczej. Centralnym punktem ciężkości w formułowaniu rozwiązań przewalczania tego mitu należałoby uczynić „uzasadnioną arbitralność” decyzji badawczej, która mogłaby się stać pełnoprawnym elementem noty metodologicznej, gdyby porzucić myślenie oczywistościowe (w myśl zasady: „jaka mapa jest - każdy wie/ widzi", a taka właśnie zasada obowiązuje najczęściej). Socjolodzy postrzegają jednak ten sposób myślenia jako naturalizowanie tego, co społeczne, poszukując prymatu zachowań motywowanych społecznie i kulturowo ponad biologią człowieka lub, co najwyżej, dialektycznego napięcia „natura-kultura" utrzymującego w równowadze istotność obu czynników przy formułowaniu wyjaśnień (niekiedy wyłącznie zaznaczając, że „natura też ma znaczenie", przy jednoczesnym problematyzowaniu drugiego członu). Równie często mamy do czynienia z mitem o przeciwstawnej proweniencji homogenizacją figuracji przestrzennych, traktowanych jako „własność gatunkowa" ludzi. Jest to uobecnienie wizji przeciwstawnej do omawianej wcześniej, która unieważnia m.in. różnice płciowe ${ }^{44} \mathrm{w}$ percypowaniu otoczenia przestrzennego, a szerzej także: kulturowe, lokalne (np. sentymenty

${ }^{4}$ Por. D. Kimura, Płeć i poznanie, Warszawa 2006, passim; A. Moir, D. Jessel, Pteć mózgu. O prawdziwej różnicy między mężczyzna a kobieta, Warszawa 2009, passim. 
przestrzenne, poczucie stabilizacji przestrzennej, więź z miastem, zakorzenienie lokalne, zakres kontaktów, zmienne ekologiczne itd.45), oraz traktuje euklidesowe, kantowskie oraz newtonowskie formy obiektywizacji przestrzennych (przód, tył, góra, dół, obok, niedaleko, w sąsiedztwie etc.) jako odpowiednio standaryzujące wielowymiarowość rzeczywistego otoczenia przestrzennego, w którym żyją ludzie w perspektywie doświadczeniowej. To przekonanie o istnieniu uniwersaliów poznania przestrzennego i możliwości stworzenia uniwersalnego systemu metrycznego, którego przyswajaniu bliżej ma być do intuicji niż uczenia się specjalnych kompetencji (np. zapoznawania $\mathrm{z}$ wiedzą kartograficzną). Ma to być zatem niczym nawiązywanie do pewnej „wiedzy wrodzonej”, a nie „wiedzy wyuczonej”. Tutaj w sukurs przychodzą, eksplorowane przez neuronauki, qualia, czyli „specyficzny stan psychiczny, jaki pojawia się u zdrowego fizycznie i psychicznie człowieka, kiedy ma on określone przeżycie zmysłowe. Stan ten polega na szczególnym doznawaniu (experience), czyli doświadczaniu jakości zmysłowych" 46 związanych ze świadomością fenomenalną. Wyodrębnianie qualiów przynależy do transgresyjnej perspektywy psychofizycznej, której daleko do jakiejkolwiek standaryzacji (także kartograficznej) i sposobów ich stanowienia (przekraczających niekiedy "nawykowe”, „powszednie” percypowanie przestrzeni, np. na bazie geometrii nie-euklidesowej). Drogą wyjścia poza ten holizm wydaje się badanie "kompetencji kartograficznej” (np. rozpoznanie jej charakteru, cech składowych i ich natężenia $w$ docelowej grupie respondentów powinno stanowić element pilotażu narzędzi badawczych i ewokować o ich ostatecznym kształcie) oraz poznawczych procesów internalizowania wiedzy geowizualnej (pewnych bazowych zasad, ogólnosocjologicznych prawidłowości - jeśli takowe udałoby się "zlokalizować" i opisać). Wiele zależy także od decyzji co do wyboru ilościowych lub jakościowych metod badawczych, rzutujących również na konstruowanie i interpretowanie narzędzi mapograficznych.

Zarówno w przypadku indywidualizacji, jak i homogenizacji doświadczeń przestrzennych standaryzacji ulega to, co społeczne, a co ze swej istoty wydaje się labilne, niejednoznaczne, wielowymiarowe. Dokonując wysubtelnienia tych krańcowo sprzecznych tendencji, socjolodzy często (zwłaszcza współcześnie) sięgają po inne mitotwórcze wyjaśnianie, jakim jest konstrukt social mind ${ }^{47}$. To przekonanie, że istnieją ucieleśnione (w sensie psycholo-

45 Prym w eksplorowaniu tych różnic wiodą badania prowadzone na Uniwersytecie Łódzkim - zarówno przez socjologów, geografów, jak i ekonomistów (np. Agnieszka Michalska-Żyła, Stanisław Mordwa, Iwona Jażdżewska, Andrzej Suliborski).

46 A. Klawiter, Wprowadzenie, [w:] Formy aktywności umystu..., t. 1, s. 294.

47 Por. koncepcje „umysłu społecznego" w kontekście mechanizmów motywacyjnych i poznawczych: S. Baron-Cohen, Rozwój zdolności czytania innych umystów: cztery etapy, [w:] 
gicznym i neuronalnym) schematy nawiązywania relacji społecznych, reagowania na zachowania innych ludzi oraz odczuwania potrzeb, które gwarantują sukces adaptacyjny jednostkom w zbiorowościach ludzkich (często pod przykrywką intencjonalnego wywoływania reakcji emocjonalnych, którym przypisujemy zupełnie inną funkcję niż ta, jaką pełnią w rzeczywistości). Skrajnym przykładem tego rozumowania są socjobiologiczne tłumaczenia kryteriów selekcji zwiększających lub zmniejszających sukces adaptacyjny (np. rozumienie altruizmu), behawioryzm społeczny G.H. Meada, ale i nurty badawcze nawiązujące do psychologii ewolucyjnej, „, nowego humanizmu" czy prac C.H. Cooleya, E. Durkheima, G. Le Bona, G. Tarde'a, L.F. Warda i właściwego im rozumienia "świadomości/duszy zbiorowej”, jako charakterystycznej dla „zwierząt społecznych”. Rozpatrywanie social mind $\mathrm{w}$ ogólnym kontekście poznania (poza płaszczyzną biologiczną) prowadzi do uznania naczelnej roli nieświadomości i ukrytych wymiarów percepcji lub tych spośród procesów poznawczych, które nie podlegają wolicjonalnej kontroli jednostkowej. Homogenizacja figuracji przestrzennych, o której była mowa przed chwilą, staje się "drugą naturą" człowieka, uniemożliwiając mu kontrolowanie tego, co w nim "społeczne", "stadne”, a tym samym mechanicyzując przedmiot zainteresowań socjologa. Nauki społeczne pozbawione zaplecza $\mathrm{w}$ postaci filozofii umysłu i psychologii poznawczej - w efekcie odnoszenia się do tego mitu - ulegają iluzji standaryzacji zachowań ludzkich oraz możliwości dokonywania ich matematycznych oszacowań, czego przykłady obserwujemy współcześnie w niektórych nurtach badań nad sieciami społecznymi, socjolingwistyce czy też w odwrocie w stronę behawioralnych teorii działań zbiorowych ${ }^{48}$.

Poza ogólnymi perspektywami poznawczymi, na poziomie których oddziaływają wspomniane mity, w praktyce socjologicznej mamy styczność również z psychosocjologicznymi mitami poznawczymi dotyczącymi wyłącznie danych geoprzestrzennych. Przykładem może być fetyszyzowanie liniowego kodowania kompetencji kulturowych, które nakazuje socjologom stawianie znaku równości pomiędzy tym, jak ludzie "czytają/rozumieją"

Formy aktywności umysłu. Ujęcia kognitywistyczne, t. 2: Ewolucja i złożone struktury poznawcze, red. A. Klawiter, Warszawa 2009, s. 145-171; P. Winkielman, P.M. Niedenthal, Ucieleśniony emocjonalny umyst społeczny, [w:] Psychologia poznania społecznego, red. M. Kossowska, M. Kofta, Warszawa 2009, s. 83-101.

48 Unieważniających tym samym klasyczną teleologię działań społecznych i mnogość motywów racjonalizujących. Por. M. Weber, Racjonalność, władza, odczarowanie, Poznań 2011, passim; E. Goffman, Analiza ramowa. Esej z organizacji doświadczenia, Kraków 2010, passim; J. Habermas, Teoria działania komunikacyjnego, t. 1: Racjonalność działania a racjonalność społeczna, Warszawa 1999, passim; H. Garfinkel, Racjonalne cechy dziatalności naukowej i potocznej, [w:] Kryzys i schizma. Antyscjentystyczne tendencje w socjologii wspótczesnej, t. 1, red. E. Mokrzycki, Warszawa 1984, s. 193-220. 
mapy otoczenia przestrzennego, a tym, jak „czytają/rozumieją” otoczenie przestrzenne samo w sobie. Odniesienie do przestrzeni, a także do jej obra$\mathrm{zu}$ jest zatem traktowane tożsamo zarówno na gruncie różnych nurtów socjologii miasta i przestrzeni, jak i w wielu innych subdyscyplinach socjologicznych, których reprezentanci posiłkują się mapami w celu zobrazowania swoich tez, rozkładu uzyskanych wyników, uczytelnienia formułowanych wniosków. Niedostrzeganie sprzeczności pomiędzy kompleksowością kartograficzną a wielowymiarowością rzeczywistości obrazowanej jest $\mathrm{w}$ przypadku korzystania $\mathrm{z}$ danych geoprzestrzennych - wyrazem technologicznie zapośredniczonego problemu głębi ontologicznej i „wielowarstwowości rzeczywistości"49. Jak należy to rozumieć? Mapy "dążą" do kompleksowości, zamknięcia, wyczerpującego zobrazowania danego obszaru według zasady jednorodności wszystkich elementów i relacji pomiędzy nimi (tzn. że wszystkie one są statyczne, przedstawialne symbolicznie itd.), gdy tymczasem rzeczywistość jest wielowymiarowa, jeśli chodzi o jakości tworzących ją elementów, porządkujące ją mechanizmy, wzajemne relacje etc. Zderzenie tych dwóch spojrzeń owocuje uznaniem rzeczywistości za uwarstwioną, a nakładanie na siebie kolejnych „warstw" kartograficznych obrazów - za głębię ontologiczną przy próbach wyjaśniania ich statusu znaczeniowego, ontologii takiego obrazu. Nie można jednak uznawać nakładania na siebie kolejnych „warstw” za przybliżanie się do rzeczywistości, lecz (jedynie) szacować w kategoriach doskonałości (mniejszej/ większej) standard danego obrazowania tego, co rzeczywiste. Struktura systemów informacji geograficznej prawdopodobnie ma mniej, niż dzisiaj sądzimy, wspólnego z umysłowym obrazem świata, rzeczywistym doświadczaniem, warunkowaniem poznawczym oraz ich neuronalnymi czy kognitywnymi korelatami, zbiorczo stanowiącymi ludzki system poznawczy, ale jest wygodnym uproszczeniem, z którym ludzki umysł bezproblemowo potrafi sobie poradzić $\mathrm{w}$ codziennym doświadczeniu (stąd rosnąca popularność systemów geoinformacyjnych operujących czytelnymi symbolizacjami). Umowność i jasność z punktu widzenia zdroworozsądkowego orientowania się $\mathrm{w}$ świecie stoi jednak $\mathrm{w}$ sprzeczności $\mathrm{z}$ wymogami naukowej ścisłości i użyteczności, w ramach konieczności wytwarzania intersubiektywnie zrozumiałych komunikatów. Skoro jednak istnieją tak znaczące rozbieżności $\mathrm{w}$ rozumieniu danych geoprzestrzennych (jakoby tworzonych na podstawie konstrukcji ludzkiego umysłu i właściwego dla niego sposobu przetwarzania doświadczeń przestrzennych), można stwierdzić, że jedyną jakością, jaką oferują, jest problematyzowanie sposobów upraszczania wielowymiarowych obrazów przestrzennych, ale nie obrazowanie tego, jak

\footnotetext{
${ }^{49}$ Ch.G.A. Bryant, op. cit., s. 265-270.
} 
o przestrzeni myślimy. Uniwersalność potocznych doświadczeń przestrzennych powinna bowiem (na poziomie mentalnym) przerastać podziały dyscyplinarne (np. na geografów i socjologów), nawet jeśli potraktujemy je nie tylko jako odrębne ścieżki dyscyplinarne, ale i jako odmienne sposoby „myślenia" o świecie, kategoryzowania jego elementów oraz sposobów ich stanowienia. Znajomość podstaw geoinformacji oraz filozofii umysłu podpowiada zatem, że nie można standaryzować "kompetencji kartograficznej” jak „kompetencji przestrzennych”, które mają charakter bardziej ogólny, także zakorzeniony w codziennym doświadczeniu, w egzystencji jednostkowej i zbiorowej (jeśli już decydujemy się na jakąkolwiek standaryzację przekraczającą ramy jednostkowego opracowania teoretycznego lub empirycznego). W przeciwnym razie generowane są trudności z oszacowaniem błędu fałszywego założenia znawstwa, paradoksu Moore'a, paradoksu operacjonalizacji itp., doskonale znane każdemu socjologowi z praktyki badawczej. Reasumując, kompetencja kompetencji nierówna, podobnie jak i poznawcze zasady ich nabywania oraz posługiwania się nimi.

Próbując podsumować wszystkie wyrażone $\mathrm{w}$ tym artykule refleksje, musimy stwierdzić, że - po pierwsze - zasadnicze nie jest pytanie o to, czy dane geoprzestrzenne są przydatne, ale o demitologizację wszystkich tych naleciałości, które nakazują wierzyć w ich obiektywizujący charakter i to w czasach, gdy coraz więcej projektów nauk szczegółowych pozbywa się tej ambicji i dywersyfikuje swoje zadania pomiędzy odnajdywanie rozwiązań dla bardzo szczegółowych zadań i problemów, często zaopatrzonych w unikatowe podstawy teoretyczne i rozwiązania narzędziowe (o czym, intuicyjnie, przekonuje już sam historyczny rozwój terminologii naukowej kartografii, np. różne "mapy tematyczne", odmienne rodzaje skal i odwzorowań etc.). Tym samym specyfika tworzenia danych przestrzennych powinna kreować specyficzne, urefleksyjnione użytki czynione $\mathrm{z}$ nich $\mathrm{w}$ kontekstach zewnętrznych względem źródła ich powstawania (np. na gruncie nauk społecznych), a nie posługiwanie się nimi w sposób bezkrytyczny. Po drugie, formułując pozytywny projekt korzystania $\mathrm{z}$ danych geoprzestrzennych $\mathrm{w}$ naukach społecznych, należy postawić pytanie o status danych przestrzennych, ich pochodzenie oraz wpływ na empiryczne kryteria trafności i rzetelności, który to wpływ jest niestwierdzalny metrycznie bez znajomości podstaw geoinformacji i geowizualizacji oraz rozpoznania „kompetencji kartograficznej" wytwórców i odbiorców tych danych (każdy bowiem standard geowizualizacji obrazowej ma za swoją podstawę pewien „rdzeń deklaratywny", np. wiedzę informatyka, tematyczne rozeznanie i poglądy twórców software'u, zdefiniowane czynnikowo kryteria użyteczności czy też szczegółowe racjonalności dostarczycieli tych danych, np. dla baz otwartych). Przykładowo, każdy, kto posługuje się geoportalami, zna z autopsji 
sytuacje, w których odnaleźć na mapach można miejsca lub obiekty faktycznie nieistniejące (lub co do których panuje takie przekonanie), a niekiedy będące efektem pospiesznego usuwania z map miejsc, których lokalizacja jest utajniona (np. bazy wojskowe) ${ }^{50}$. Po trzecie, ważniejsze niż próby powracania do organicystycznego i mentalistycznego antropomorfizowania nauki współczesnej (vide dążenie do logicznej i mentalnej zbieżności map z konstruowaniem wyobrażeń przestrzennych na poziomie umysłu) wydaje się rzetelne informowanie o jej (nauki) podstawach i kierunkach pochodzenia refleksji (o kierunkach docelowych nie wspominając). Istotniejsza wydaje się zatem etnografia myśli naukowej niż próba jej umocowania w schematach poznawczych właściwych refleksyjności potocznej lub naukowej (bo choć ułatwia to zrozumienie założeń lub usprawnia proces komunikacji, to zarazem wypacza ich sens, niekiedy kodując zafałszowany i ideologizujący obraz u zainteresowanych). Na zakończenie, cytując Metodologię nauk Adama Groblera (choć cytat ten dotyczy zupełnie innego kontekstu), można powiedzieć następująco: „Przedstawmy sobie dziedzinę nauki jako mapę konturową. Badanie tak określonej dziedziny będzie polegało na wypełnianiu map konturowych różnych regionów interesującymi nas szczegółami. Jakimi? Zależy od rodzaju mapy [wyróżnienie moje - P.L.]: od tego, czy jest to mapa fizyczna, polityczna, administracyjna, drogowa, gospodarcza i tak dalej. Każdy rodzaj map odpowiada, przy tej analogii, innej dziedzinie nauki. Fakt, że między dziedzinami zachodzą wielorakie związki, odzwierciedla wymóg zgodności map: na przykład układ rzek na mapie fizycznej i drogowej musi być taki sam. Nie ma żadnej Idealnej Mapy. Inne mapy są potrzebne na wyprawę samochodową, a inne do gry w podchody. Mapa jest abstrakcyjną reprezentacją terenu, toteż pojęcie stopnia podobieństwa jako kryterium jakości mapy nie ma żadnego zastosowania [wyróżnienie moje - P.L.]. Kółeczko oznaczające miasto nie ma nic wspólnego z kształtem jego granic, a rozmiary znaków hoteli i stacji benzynowych nie zachowują rzeczywistych proporcji wielkości obiektów. Są mapy lepsze i gorsze ze względu na określone potrzeby, i tym potrzebom, a nie zachowaniu podobieństw, są podporządkowane konwencje reprezentowania. A że są mapy lepsze i gorsze, można je ulepszać, czyli dążyć do ideału, mimo że żadnego ideału nie ma. Tak samo nauka może dążyć do prawdy, nawet jeżeli nie ma nic takiego jak Prawda Absolutna"51. Mapa jako metafora nauki, a także metafora "w" nauce, to jednak temat na zupełnie odrębny artykuł.

${ }^{50} \mathrm{~W}$ Internecie można znaleźć wiele stron i amatorskich filmów poświęconych tej tematyce, np. http://www.mapofstrange.com/ [dostęp: 30.11.2012], http://www.popcrunch. com/22-unexplainable-mysteries-spotted-on-google-maps/?img=162445 [dostęp: 30.11.2012], http://www.youtube.com/watch?v=ucFLFKOC_b8 [dostęp: 30.11.2012].

51 A. Grobler, Metodologia nauk, Kraków 2008, s. 308-309. 


\section{BIBLIOGRAFIA}

1000 stów o mapach i kartografii, red. J. Drabek, F. Piątkowski, Warszawa 1989.

Andrzejewska M. et al., O partycypacji społecznej w planowaniu przestrzennym. Zastosowania geowizualizacji $w$ celu wzmocnienia udziatu społecznego w planowaniu przestrzennym, 2007, http://pspe.gridw.pl/movies/O\%20partycypacji_spolecznej.pdf [dostęp: 30.11.2012].

Baron-Cohen S., Rozwój zdolności czytania innych umystów: cztery etapy, [w:] Formy aktywności umystu. Ujęcia kognitywistyczne, t. 2: Ewolucja i złożone struktury poznawcze, red. A. Klawiter, Warszawa 2009.

Bryant Ch.G.A, Socjologia bez podstaw, [w:] Racjonalność wspótczesności. Między filozofia a socjologia, red. H. Kozakiewicz, E. Mokrzycki, M.J. Siemek, Warszawa 1992.

Crowley R., gCommerce. How GIS is facilitating modern business, 2006, http://www. ronancrowley.com/NCI/gCommerce.pdf [dostęp: 30.11.2012].

Daniel S., O'Rourke K., Mapping the Database: Trajectories and Perspectives, "Leonardo” 2004, no. 4(37), s. 287-296.

Feyerabend P.K., Przeciw metodzie, Wrocław 2001.

Frith Ch., Od mózgu do umystu. Jak powstaje nasz wewnętrzny świat, Warszawa 2011.

Fu P., Sun J., Web GIS: Principles and Applications, Redlands 2010.

Garfinkel H., Racjonalne cechy działalności naukowej i potocznej, [w:] Kryzys i schizma. Antyscjentystyczne tendencje w socjologii wspótczesnej, t. 1, red. E. Mokrzycki, Warszawa 1984.

Gaździcki J., hasło: „geoportal”, 2010, http:/ / ptip.org.pl/ [dostęp: 30.11.2012].

Gaździcki J., hasło: „metadane”, 2010, http://ptip.org.pl/ [dostęp: 30.11.2012].

Gaździcki J., hasło: „usługi danych przestrzennych”, 2010, http://ptip.org.pl/ [dostęp: 30.11.2012].

Gilson O., Silva N., Grant P.W., Chen M., From Web Data to Visualization via Ontology Mapping, „Computer Graphics Forum” 2008, no. 3(27), s. 959-966.

Goffman E., Analiza ramowa. Esej z organizacji doświadczenia, Kraków 2010.

Gotlib D., Iwaniak A., Olszewski R., Obszary zastosowań, Warszawa 2007.

Griswold W.G., Yuan J.J., Kato Y., Exploiting the Map Metaphor in a Tool for Software Evolution, [w:] ICSE '01 Proceedings of the 23rd International Conference on Software Engineering, ed. H.A. Müller, Washington 2001, s. 265-274

Grobler A., Metodologia nauk, Kraków 2008.

Habermas J., Teoria działania komunikacyjnego, t. 1: Racjonalność działania a racjonalność społeczna, Warszawa 1999.

Ittelson W.H., Environmental Perception and Urban Experience, „Environment and Behavior" 1978, no. 2(10), s. 193-213.

Ittelson W.H., Visual Space Perception, New York 1960.

Kimura D., Płeć i poznanie, Warszawa 2006.

Kisielewicz A., Sztuczna inteligencja i logika. Podsumowanie przedsięwzięcia naukowego, Warszawa 2011.

Klawiter A., Wprowadzenie, [w:] Formy aktywności umystu. Ujęcia kognitywistyczne, t. 1: Emocje, percepcja, świadomość, red. A. Klawiter, Warszawa 2008.

Klawiter A., Wstęp do kognitywistyki. Wykład siódmy, http://www.staff.amu.edu.pl/ klawiter/wstep-wyklad7-2010.pdf [dostęp: 30.11.2012].

Kozak J., GIS jako nowe narzędzie badań geograficznych: czy tylko?, „Alma Mater” 2006, nr 85 , s. 22-24. 
Longley P.A., Goodchild M.F., Maguire D.J., Rhind D.W., GIS. Teoria i praktyka, Warszawa 2008.

Medyńska-Gulij B., Kartografia i geowizualizacja, Warszawa 2011.

Miłkowski M., Obliczeniowe teorie świadomości, „Analiza i Egzystencja” 2010, nr 11, s. 133-154.

Miłkowski M., Poczobut R., Wprowadzenie, [w:] Przewodnik po filozofii umystu, red. M. Miłkowski, R. Poczobut, Kraków 2012.

Moir A., Jessel D., Płeć mózgu. O prawdziwej różnicy między mężczyzna a kobietą, Warszawa 2009.

Nawratek K., Ideologie w przestrzeni. Próby demistyfikacji, Kraków 2005.

Osowski F., Brokman L., Elementy kartografii. Redagowanie i reprodukcja map, Warszawa 1984.

Penrose R., Cienie umystu. Poszukiwanie naukowej teorii świadomości, Poznań 2000.

Penrose R., Nowy umyst cesarza. O komputerach, umyśle i prawach fizyki, Warszawa 2000.

Przewłocki S., Geomatyka, Warszawa 2009.

Robinson A., Sale R., Morrison J., Podstawy kartografii, Warszawa 1988.

Saliszczew K.A., Kartografia ogólna, Warszawa 2003.

Searle J.R., Umyst na nowo odkryty, Warszawa 1999.

Sui D.Z., Goodchild M.F., GIS as Media?, „International Journal of Geographical Information Science" 2001, no. 5(15), s. 387-390.

Weber M., Racjonalność, władza, odczarowanie, Poznań 2011.

Winkielman P., Niedenthal P.M., Ucieleśniony emocjonalny umyst społeczny, [w:] Psychologia poznania społecznego, red. M. Kossowska, M. Kofta, Warszawa 2009.

http://opensourcegis.org/ [dostęp: 30.11.2012].

http://pl.wikipedia.org/wiki/Geotagging [dostęp: 30.11.2012].

http://www.intergraph.com/sgi/products/default.aspx [dostęp: 30.11.2012].

http://www.mapofstrange.com/ [dostęp: 30.11.2012].

http:/ / www.popcrunch.com/22-unexplainable-mysteries-spotted-on-google-maps /

?img=162445 [dostęp: 30.11.2012].

http:/ /www.youtube.com/watch?v=7rGOj8TSHH4 [dostęp: 30.11.2012].

http://www.youtube.com/watch?v=ucFLFKOC_b8 [dostęp: 30.11.2012]. 